\title{
152. 屋外昼光照度の代表値
}

\author{
そその 2 側空採光について・
}

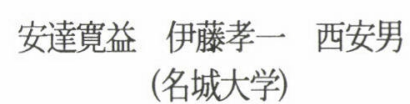

序

昼光の有効利用を目指し、室内採光照度の予測について試 みている。太陽高度 $\mathrm{h}$ の推移により、刻々変動する野外昼光 照度は晴·量·雨天時によっても大きく変わる。「その 2」では 側空についてであり、測定対象光源を $1 / 2$ 全天空光源として 捕らえ4 方位について測定を行なっている。したがって、側空 採光において室内の視作業面に直接影響する照度は室内水平 視作業面の直接照度を天空光源より求めた。

測定デ-㚈おける 4 方位 $1 / 2$ 全天空による照度をもとに、 主変動要因である晴天·最天・雨天に データより代表值の導出を行なった。

\section{対象天空と測定}

室内被照点が側空に限りなく近接した場合をもって最大の 測定対象天空領域となり、その光源領域は $1 / 2$ 全天空となる。 側空とした $1 / 2$ 全天空光源照度は東午前 (西午後) ·東午後 (西 午前) ·南·北4方位に大別して表わすことにした。

4 方位 $1 / 2$ 天空領域の照度測定には 4 方位に天空を遮避す る遮光板を設置し、その遮光板には照度計を水平固定し $1 / 2$ 全天空となるようにしている。

測定デー夕の収録は 0 時から 24 時であり、測定刘象は日出 から日没まで 1 分ごとのデ -夕を10分間隔に平均した值として PCに収録させている。

\section{測定拮果}

測定值より春·秋季, 夏季, 冬季および年間それぞれについ

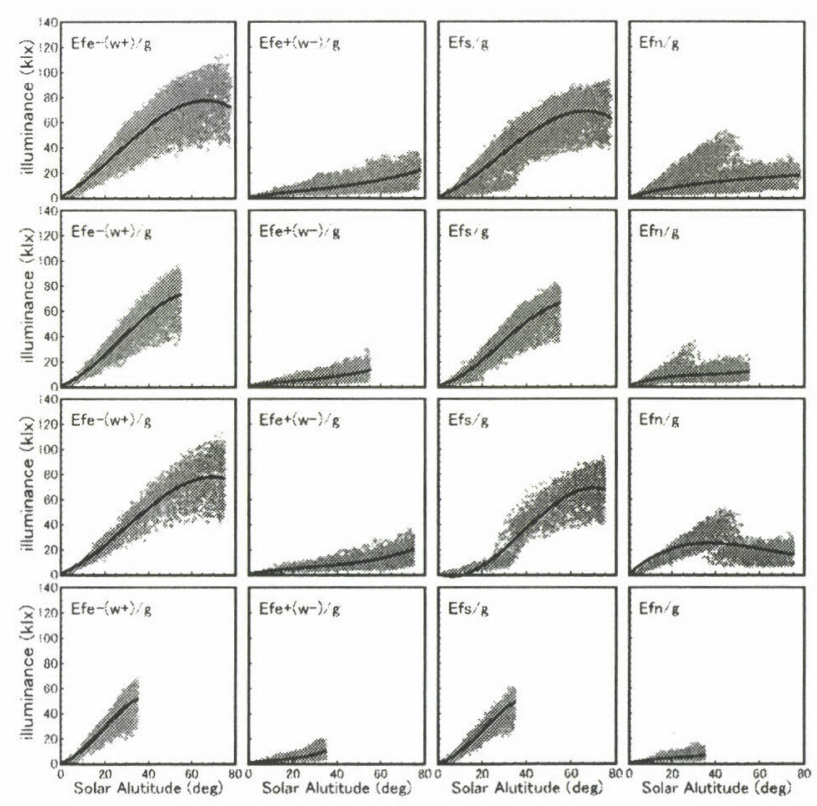

図1. 晴・1/2グローバ燳度の測定照度分布と回帰曲線
て、晴・4 方位 $1 / 2$ 全天空における照度分布を図 1 に表わした。 各図中の実曲線は最小自乗法による回帰である。

また、図2.a,b, c,dは晴4万位1/2全天空についてであり、 図 $\mathrm{e}, \mathrm{f}$ は最・雨 $1 / 2$ 全天空の 4 方位平均照度について、それ

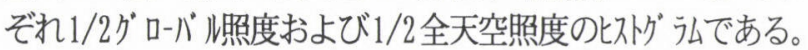

各方位ともに中央值が平均·最頻の值の中庸にある。そのた め、代表值を中央值(正規分布とみなし)と定めた。

\section{結び}

側空採光照度における対象光源は $1 / 2$ 全天空として測定を 行い、測定デー夕夕晴天·量天・雨天時における $1 / 2$ グローバ炤度 と $1 / 2$ 全天空照度を収録することができた。

天空光源照度についは統計処理を行い、天気別各方位の代 表照度となる 1 值を表 1 に示すことができた。
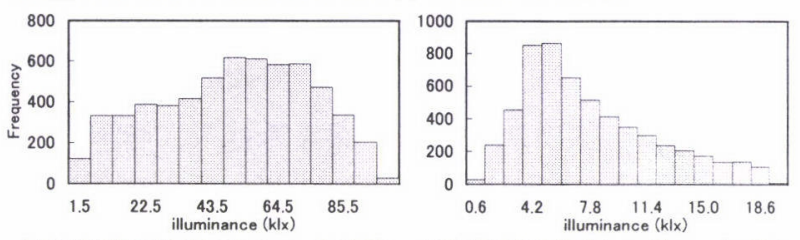

a) 晴·東午前(西午後)·1/2グローバル照度
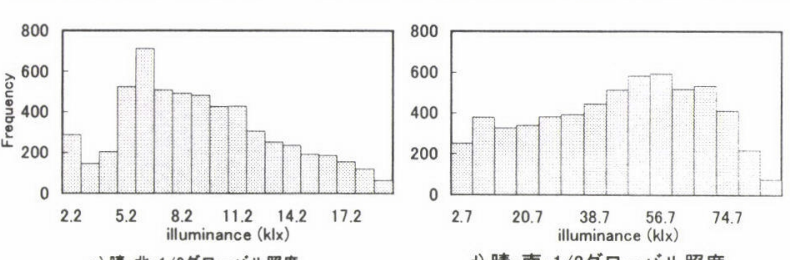

c) 晴·北・1/2グローバル照度

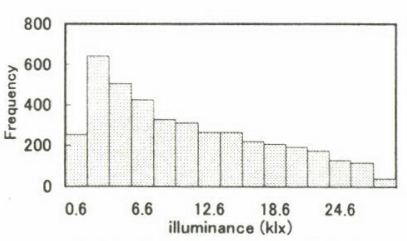

d）晴·南·1/2グローバル照度

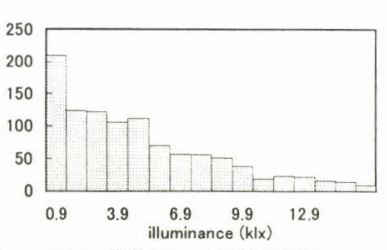

d) 年·位平均·1/2全天空照度

図 2 晴・4 方位 $1 / 2 ク^{*}$ ロハバ照度, および 量雨 4 方位平均 $1 / 2$ 全天空照度の圤外 弘

表 1 各天空光源の照度值 平均值 $(\mathrm{lx})$ 中央值 $(\mathrm{lx})$ 最頻值 $(\mathrm{lx})$

\begin{tabular}{c|c|c|c}
\hline & 平均值(lx) & 中央值 $(\mathrm{lx})$ & 最頻值 $(\mathrm{lx})$ \\
\hline \hline $\mathrm{Efe}-(\mathrm{w}+) / \mathrm{g}$ & 46952 & 49073 & 57452 \\
\hline $\mathrm{Efe}(\mathrm{w}-) / \mathrm{g}$ & 7161 & 6066 & 5361 \\
\hline $\mathrm{Efs} / \mathrm{g}$ & 41685 & 44217 & 56685 \\
\hline $\mathrm{Efn} / \mathrm{g}$ & 8672 & 8145 & 6172 \\
\hline $\mathrm{Ec} 4 / \mathrm{s}$ & 9580 & 7795 & 2580 \\
\hline $\mathrm{Er} 4 / \mathrm{s}$ & 4418 & 3530 & 918 \\
\hline
\end{tabular}

参考文献; 安達寛益,伊藤孝一,西安男: 野外昼光照度の年間評価 側空採 光による室内照度予測 (その2)、日本建築学会東海支部研究報 告、第 40 号 pp.393 396 (2002 年 2 月)

Representative Value of Outdoor Daylight Illuminance- Part2. Side Lighting- Hiromitsu Adati 